\title{
Thrombin obliteration of subclavian artery aneurysm with intravascular balloon protection
}

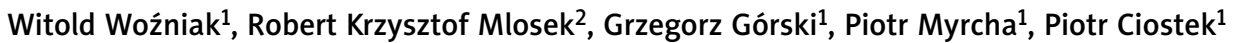 \\ ${ }^{1}$ First Department of General and Vascular Surgery, Second Faculty of Medicine with the English Division \\ and the Physiotherapy Division, Medical University of Warsaw, Poland \\ 2Department of Ultrasonographic Diagnostics and Mammography, Second Faculty of Medicine \\ with the English Division and the Physiotherapy Division, Medical University of Warsaw, Poland
}

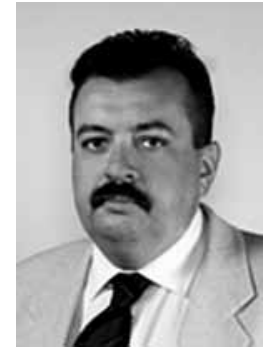

Kardiochirurgia i Torakochirurgia Polska 2014; 11 (2): 202-204

\begin{abstract}
A rare case of a 56-year-old man with posttraumatic false aneurysm of the right subclavian artery is presented. He was admitted to hospital due to pain in the shoulder. The diagnosis was made upon ultrasonography and computed tomography (CT) results. With ultrasound guidance, the aneurysm was punctured and injected with bovine thrombin (Biotrombina $400 u$, Biomed). During the injection, the aneurysm neck was occluded by an endovascular balloon placed in the subclavian artery. Complete aneurysm embolisation was confirmed by ultrasound and CT studies. The postoperative course was complicated by Horner's syndrome which resolved completely within 3 weeks. The procedure technique is described in detail. Key words: subclavian artery pseudoaneurysm, vascular injury, embolisation.
\end{abstract}

False aneurysms of the subclavian artery are relatively rare. They are usually either the result of penetrating or blunt trauma or iatrogenic [1, 2]. Various anatomical structures in the vicinity of the subclavian artery are responsible for complex and heterogeneous clinical symptoms. A considerable part of the clinical picture may be the result of microembolisation. The classical surgical procedure associated with resection and reconstruction of the damaged artery has been nowadays replaced by miniinvasive procedures. These are either percutaneous ultrasound-guided thrombin injection, endovascular coil embolisation, or covered stent placement. This patient has been treated with a combined endovascular and percutaneous ultrasound-guided approach.

\section{Case report}

A 56-year-old man with a history of hypertension presented with pain in the neck and suprascapular region.

\section{Streszczenie}

W pracy przedstawiono rzadki przypadek 56-letniego mężczyzny z pourazowym rzekomym tętniakiem prawej tętnicy podobojczykowej. Chory został przyjęty do szpitala z powodu bólu barku, a rozpoznanie ustalono na podstawie badania ultrasonograficznego (USG) i angiografii tomografii komputerowej. Wykonano embolizację tętniaka za pomocą trombiny bydlęcej podanej pod kontrolą USG. Podczas iniekcji szyję tętniaka zabezpieczono balonem wewnątrznaczyniowym rozprężonym w tętnicy podobojczykowej prawej. Skuteczność embolizacji potwierdzono badaniem angiografii tomografii komputerowej. Przebieg pooperacyjny był powikłany wystąpieniem zespołu Hornera, który ustąpił po 3 tygodniach. W pracy dokładnie przedstawiono technikę postępowania chirurgicznego.

Słowa kluczowe: pourazowy rzekomy tętniak tętnicy podobojczykowej, uszkodzenia naczyń, embolizacja.

The patient gave a history of blunt trauma of this region some two weeks earlier. He was crushed incidentally by another man, following an episode of alcohol abuse.

Ultrasound study of the supraclavicular area showed a false aneurysm of the right subclavian artery. Further details were obtained upon CT angiography (Fig. 1). The patient was scheduled for endovascular treatment. The angiogram of the aortic arch performed via the left common femoral artery demonstrated false aneurysm. However, even selective angiogram of the right subclavian and right common carotid arteries could not precisely visualise the aneurysm neck. Then subclavian artery aneurysm was directly punctured under ultrasound guidance, and a selective angiogram was performed. This depicted exactly the false aneurysm neck in the right subclavian artery. In order to avoid thrombin backflow to the subclavian/carotid vessels, a balloon was placed in the right subclavian artery. 

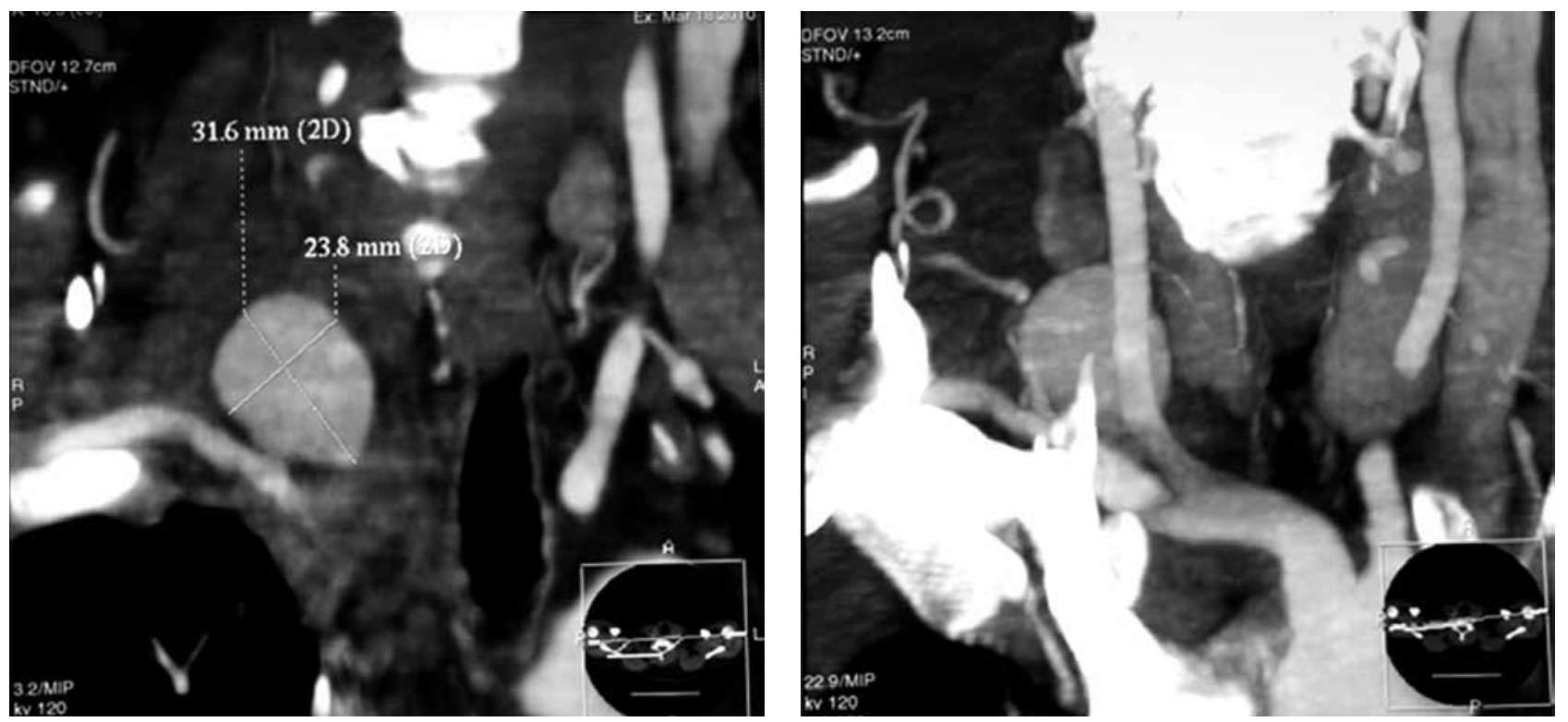

Fig. 1. Computed tomography angiography depicts the right subclavian artery false aneurysm

The balloon was expanded and - simultaneously - Doppler ultrasonography examination under the control of colourcoded ultrasonography was performed in order to verify that the flow in the aneurysm had ceased. This indicated that the catheter balloon was in the proper position and the aneurysm obliteration by thrombin could be securely performed. 400 units of bovine thrombin were administered through a needle into the aneurysm sac. The control angiogram demonstrated patent subclavian and common carotid arteries. Neither the angiogram nor ultrasound demonstrated blood flow within the false aneurysm. On the second day, control CT angiography was carried out, which confirmed the exclusion of the right subclavian artery false aneurysm (Fig. 2). On the first postoperative day, Horner's syndrome signs were observed. They gradually withdrew within 21 days. Follow-up ultrasonography examination was performed following 1, 3, 6, 12 and 24 months. These examinations did not indicate flow within the aneurysm, but gradual diminution of the thrombosed aneurismal sac was observed.

\section{Discussion}

Open surgical treatment of subclavian artery aneurysms is a technically complicated procedure. The most commonly used option is ligation of the proximal part of the subclavian artery. Following aneurysm excision, blood flow is usually restored with an inlay prosthesis - either a synthetic or an autologous venous graft. In the case of a large massive an-
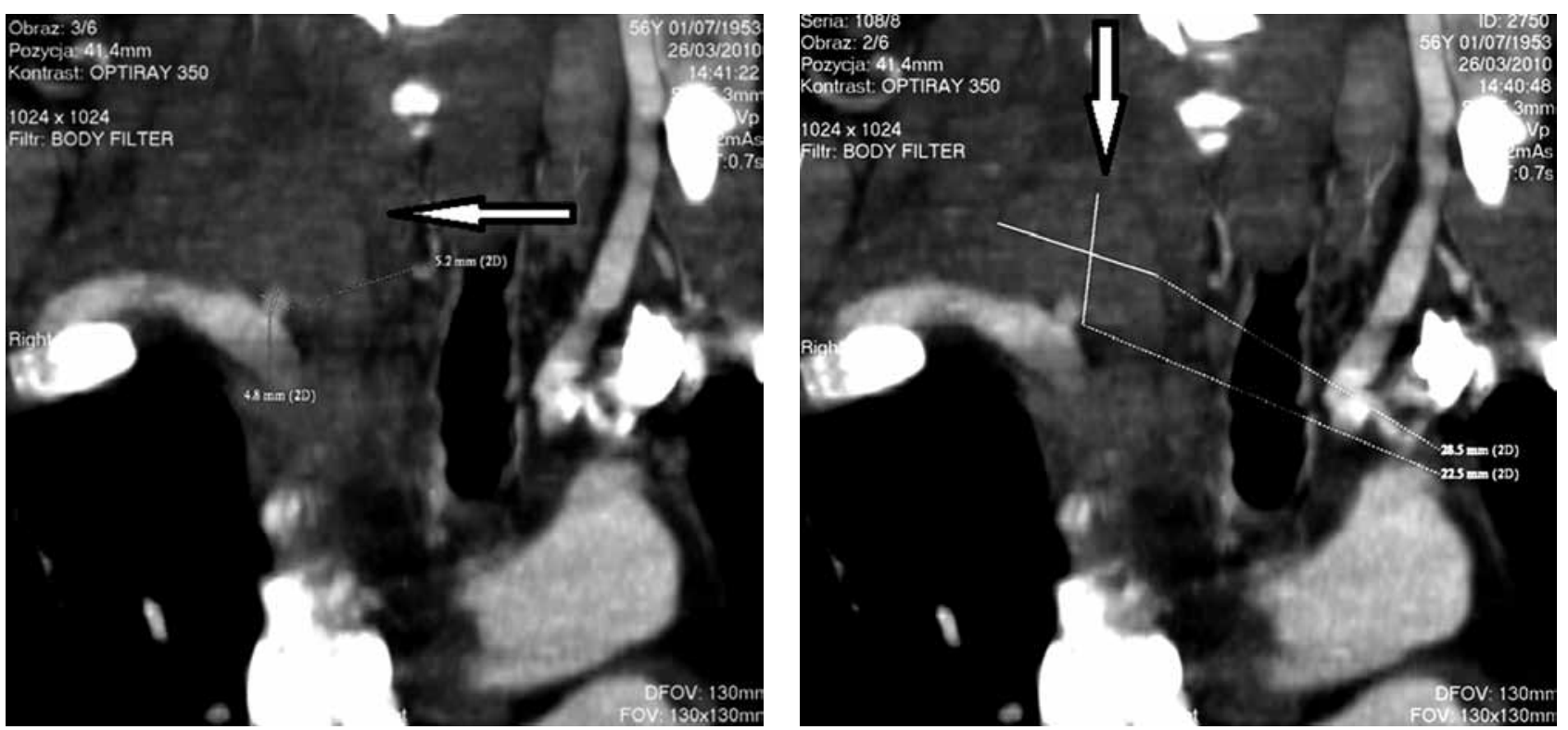

Fig. 2. Control angiography of computed tomography shows the obturation of the right subclavian artery aneurysm (an arrow indicates the aneurysm stub) 
eurysm, such a procedure is often impossible to perform. In such a case blood flow is restored interposition of the subclavian artery to the carotid artery or by carotid-subclavian or subclavian-subclavian bypass. These complicated surgical procedures usually require thoracotomy and sternotomy, often complemented with an additional supraclavicular incision. The risk of such an operation in circulatory compromised patients is significant [3].

The development of endovascular techniques significantly facilitated treatment of subclavian artery aneurysms. The use of stent grafts enables simultaneous aneurysm exclusion and anatomical reconstruction of blood flow. The follow-up period of the patients after the operation in general does not exceed 3 years. Therefore long-term results are still unknown. Open surgery for subclavian artery aneurysm still remains the treatment of choice in the majority of medical centres [4].

Endovascular restoration of blood flow distally to the aneurysm is not always possible. In these cases some authors propose an alternative involving coil embolisation of the aneurysmal lumen followed by open surgical bypass, usually carotid-subclavian [5].

In the case of the patient treated in our clinic we used a minimally invasive technique. Initially an intra-arterial balloon was expanded in the subclavian artery at the site of the leakage. This aimed at obstructing the flow within the aneurysm in order to effectively protect the subclavian artery from distal embolisation/clotting. Then under ultrasound guidance, the sac of the right subclavian artery false aneurysm was injected with thrombin, resulting in complete embolisation of the aneurysm. Direct administration of radiological contrast into the aneurysm sac also enabled precise localisation of the site of leakage (aneurysm neck), which was not possible in a classical intra-arterial angiogram.

The transcutaneous thrombin administration technique under ultrasound guidance is widely used in treatment of iatrogenic false aneurysms of the common femoral artery, resulting from arterial cannulation prior to the endovascular procedure. Such a method in subclavian artery aneurysm management is rarely reported. Kang et al. described one case of effective thrombin embolisation of subclavian artery aneurysm. The aneurysm was of iatrogenic origin the result of subclavian vein cannulation [6]. With reference to false aneurysms of the subclavian artery, a covered stent is regarded as the treatment of choice, whilst thrombin administration is a second choice procedure. A recent publication discussed a case of leakage following insertion of a stent graft into the subclavian artery, which was successfully obturated by thrombin injection. However, no balloon protection was used in that case [7].

Leakage of thrombin into the systemic circulation can trigger a systemic arterial embolism. For this reason, as well as for fear of potential microembolisation, thrombin injection is relatively rarely used. In order to protect the patient from these complications, an endovascular balloon was expanded in the subclavian artery, with subsequent aneurysm neck closure. This technique had been previously applied in the embolisation of femoral artery false aneurysms [8]. From a vascular surgeon's point of view, this method of subclavian artery false aneurysm management is relatively simple, efficacious and safe. Over a one-year follow-up period the procedure efficacy was confirmed.

Taking into account a variety of complicated therapeutic methods - stent graft implantation, bypass surgery - we regard the thrombin injection method as a technically very simple solution. It is also undoubtedly the cheapest one. Due to the low incidence of subclavian artery false aneurysms, precise analysis of treatment results would demand multi-centre cooperation.

\section{References}

1. Thies E, Otto M, Wolff R, Volesky A. Traumatic false aneurysm of the subclavian artery. Aktuelle Traumatol 1993; 23: 133-137 [in German].

2. Baldwin RT, Kieta DR, Gallagher MW. Complicated right subclavian artery pseudoaneurysm after central venipuncture. Ann Thorac Surg 1996; 62: 581-582.

3. Pairolero PC, Walls JT, Payne WS, Hollier LH, Fairbairn JF 2nd. Subclavianaxillary artery aneurysms. Surgery 1981; 90: 757-763.

4. Hilfiker PR, Razavi MK, Kee ST, Sze DY, Semba CP, Dake MD. Stent-graft therapy for subclavian artery aneurysms and fistulas: single-center midterm results. J Vasc Interv Radiol 2000; 11: 578-584.

5. Bush RL, Lin PH, Najibi S Dion JE, Smith RB 3rd. Coil embolization combined with carotid-subclavian bypass for treatment of subclavian artery aneurysm. J Endovasc Ther 2002; 9: 308-312.

6. Kang SS, Labropoulos N, Mansour MA Michelini M, Filliung D, Baubly MP, Baker WH. Expanded indications for ultrasound-guided thrombin injection of pseudoaneurysms. J Vasc Surg 2000; 31: 289-298.

7. Lee GS, Brawley J, Hung R. Complex subclavian artery pseudoaneurysm causing failure of endovascular stent repair with salvage by percutaneous thrombin injection. J Vasc Surg 2010; 52: 1058-1060.

8. Owen RJ, Haslam PJ, Elliott ST, Rose JD, Loose HW. Percutaneous ablation of peripheral pseudoaneurysms using thrombin: a simple and effective solution. Cardiovasc Intervent Radiol 2000; 23: 441-446. 